\title{
Acquisition of photosensitivity in castrated male starlings (Sturnus vulgaris) under short day photoperiods
}

\author{
M. S. Boulakoud and A. R. Goldsmith* \\ AFRC Research Group on Photoperiodism and Reproduction, Department of Zoology, School of \\ Biological Sciences, University of Bristol, Bristol BS8 1UG, UK
}

\begin{abstract}
Photorefractory castrated male starlings were transferred from a photoperiodic schedule of $18 \mathrm{~h}$ light: $6 \mathrm{~h}$ dark to $1 \mathrm{~h}$ light: $23 \mathrm{~h}$ dark, $5 \mathrm{~h}$ light:19 h dark, $8 \mathrm{~h}$ light:16 h dark or $11 \mathrm{~h}$ light:13 h dark. Plasma concentrations of LH were measured in blood samples taken at regular intervals, to give an indication of the reacquisition of photosensitivity under these schedules. Concentration of plasma LH increased after 35, 38, 35 and 63 days, respectively; there was a steady increase in $\mathrm{LH}$ in all groups, but the increase under $11 \mathrm{~h}$ light:13 h dark was much slower than in the other groups. In contrast, birds held under $18 \mathrm{~h}$ light: $6 \mathrm{~h}$ dark showed no increase in LH. Thus, starlings became photosensitive at a similar rate under fixed photoperiods of $8 \mathrm{~h}$ light:16 h dark or shorter, but took longer to acquire photosensitivity under $11 \mathrm{~h}$ light:13 $\mathrm{h}$ dark.
\end{abstract}

\section{Introduction}

European starlings, Sturnus vulgaris, in common with most other birds that become absolutely photorefractory under long daily photoperiods, require a period of exposure to short days before they regain photosensitivity and can again become reproductively active in response to long-day stimulation (Nicholls et al., 1988). The acquisition of photosensitivity is normally completed by early November in southern England, at which time there is a spontaneous increase in concentrations of LH in plasma in castrated birds (Dawson and Goldsmith, 1984). The change in plasma LH after castration reliably indicates the distinction between photorefractoriness and photosensitivity in starlings maintained in a controlled laboratory environment. Male starlings held under long days ( $16 \mathrm{~h}$ light: $8 \mathrm{~h}$ dark) after gonadal regression show no change in LH after castration, whereas a rapid increase in LH occurs after castration of photosensitive birds maintained under short days (8 h light:16 h dark; Goldsmith and Nicholls, 1984a).

The time course of the increase in plasma LH in castrated photorefractory starlings after they have been transferred to short days ( $8 \mathrm{~h}$ light: $16 \mathrm{~h}$ dark) correlates well with a gradual development of photosensitivity as determined by testicular growth rate in intact birds in response to photostimulation with long days ( $18 \mathrm{~h}$ light: $6 \mathrm{~h}$ dark). Concentrations of $\mathrm{LH}$ in castrated males are increasing after 4 weeks and are maximal after 6 weeks of exposure to $8 \mathrm{~h}$ light:16 h dark (Goldsmith and Nicholls, 1984b). In a separate series of experiments, initially photorefractory intact male starlings were tested for their gonadal response to $18 \mathrm{~h}$ light: $6 \mathrm{~h}$ dark after different times of exposure to $8 \mathrm{~h}$ light:16 h dark (Boulakoud, 1990). After 2 weeks of $8 \mathrm{~h}$ light:16 h dark, there was no testicular development upon transfer to $18 \mathrm{~h}$ light: $6 \mathrm{~h}$ dark; after 4 weeks of $8 \mathrm{~h}$

Received 22 February 1993. light:16 h dark there was a low amplitude testicular cycle; and after 6 weeks of $8 \mathrm{~h}$ light:16 h dark the gonadal response to $18 \mathrm{~h}$ light: $6 \mathrm{~h}$ dark was as large as in birds that had been exposed to $8 \mathrm{~h}$ light: $16 \mathrm{~h}$ dark for 10 weeks.

The extent to which development of photosensitivity is influenced by the duration of the photophase of a 'short' day (rather than the duration of exposure of birds to a fixed short photoperiod), was investigated here. Photoperiodic experiments involving the measurement of the $\mathrm{LH}$ response to castration have shown that refractory starlings become photosensitive more rapidly under $8 \mathrm{~h}$ light: $16 \mathrm{~h}$ dark than under $11 \mathrm{~h}$ light: $13 \mathrm{~h}$ dark, which in turn is more effective than $12 \mathrm{~h}$ light:12 h dark (Dawson, 1991). The response under $6 \mathrm{~h}$ light: $18 \mathrm{~h}$ dark was similar to, possibly slightly faster than, the response to $8 \mathrm{~h}$ light: $16 \mathrm{~h}$ dark, while daylengths shorter than $6 \mathrm{~h}$ light: $18 \mathrm{~h}$ dark were not tested. It is well known that under all photoperiods longer than $12 \mathrm{~h}$ light: $12 \mathrm{~h}$ dark starlings remain indefinitely photorefractory. In this study, castrated male starlings were tested for photosensitivity under a number of fixed photoperiods shorter than $8 \mathrm{~h}$ light: $16 \mathrm{~h}$ dark. We attempted to define the limits of the short-day response, to provide information on the range of photoperiodic responses and to discover whether there is a finite limitation to the rate at which the underlying endocrine and neuroendocrine processes can proceed.

\section{Materials and Methods}

\section{Animals}

Starlings, Sturnus vulgaris, were captured locally and kept initially in an outdoor aviary. After three weeks they were transferred indoors and kept in light-controlled rooms, in aluminium cages measuring $0.6 \mathrm{~m} \times 0.5 \mathrm{~m} \times 0.4 \mathrm{~m}$, with six to 


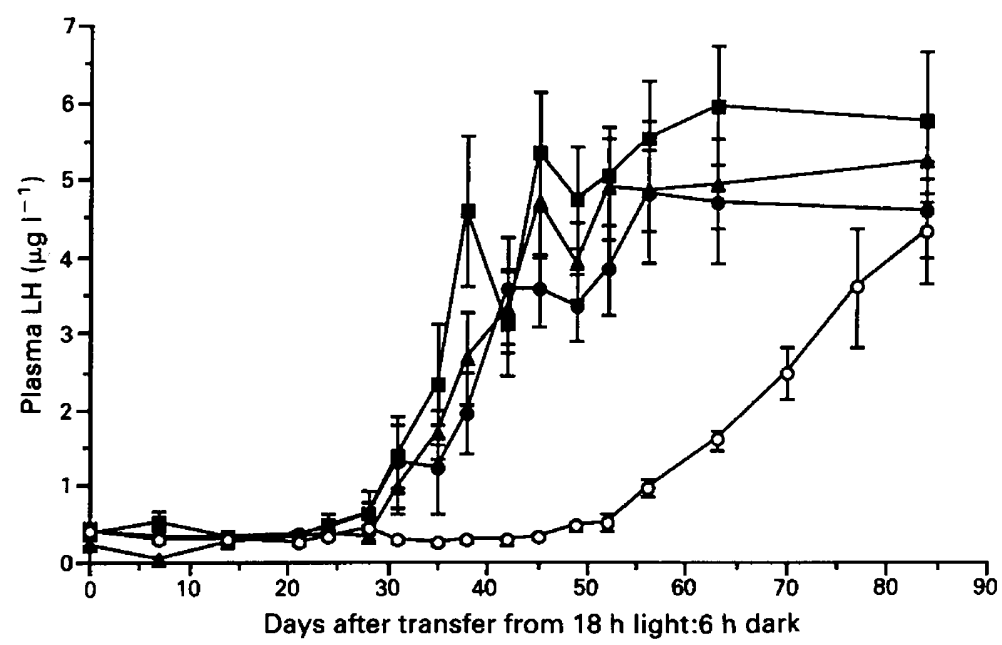

Fig. 1. Plasma concentration of luteinizing hormone (LH) in castrated male starlings transferred from a photoperiod of $18 \mathrm{~h}$ light: $6 \mathrm{~h}$ dark to $1 \mathrm{~h}$ light: $23 \mathrm{~h}$ dark (A), $5 \mathrm{~h}$ light:19 h dark (O), $8 \mathrm{~h}$ light:16 h dark (ם) or to $11 \mathrm{~h}$ light:13 h dark $(O)$. Values are means \pm SEM and numbers of birds per group were $7,7,6$ and 6 , respectively.

eight birds per cage. The sex of the birds was ascertained by laparotomy under general anaesthesia, after i.m. injection of $70 \mu \mathrm{l}$ Sagatal (Wyvern Vet. Co., Chepstow) containing $4.2 \mathrm{mg}$ sodium pentobarbitone. Male birds were castrated, again under pentobarbitone anaesthesia. The testes were removed through bilateral incisions between the last two ribs. The castrated starlings were exposed to a photoperiod of $18 \mathrm{~h}$ light: $6 \mathrm{~h}$ dark to induce a reproductive cycle, and were kept under this daylength until plumage moult was complete (20 weeks). They were then divided into groups, with six or seven birds in each group, and transferred into photoperiodic chambers with the daylength set to I h light: $23 \mathrm{~h}$ dark, $5 \mathrm{~h}$ light:19 h dark, $8 \mathrm{~h}$ light:16 h dark or $11 \mathrm{~h}$ light:13 h dark. A further six castrated starlings were maintained under $18 \mathrm{~h}$ light: $6 \mathrm{~h}$ dark.

Blood samples were collected at regular intervals, beginning on the day before the photoperiod was changed. Approximately $0.4 \mathrm{ml}$ of blood was collected from the wing vein into heparinized capillary tubes. Samples were centrifuged at $1200 \mathrm{~g}$ for $10 \mathrm{~min}$, and the plasma was stored at $-20^{\circ} \mathrm{C}$. The blood samples were always collected from birds during the first hour after dawn, to coincide with the light period of the $1 \mathrm{~h}$ light: $23 \mathrm{~h}$ dark group.

\section{Hormone assays}

Concentrations of $\mathrm{LH}$ were measured in the plasma using the homologous chicken LH assay described by Follett et al. (1972), using an anti-chicken LH antiserum (code anti-IRC2T, supplied by B. K. Follett, Department of Zoology, University of Bristol) at a final concentration of $1: 6000$. The lowest detectable dose was $0.05 \mu \mathrm{g} \mathrm{l}^{-1}$, and the intra-assay coefficient of variation for a starling plasma pool measured six times within the assay was $6.9 \%$. All samples from the present experiment were measured in duplicate $20 \mu \mathrm{l}$ volumes in a single assay.

\section{Statistical analysis}

Changes in LH concentration within each experimental group were analysed using repeated-measures analysis of variance; comparisons between means were made using the Fisher PLSD test. Comparisons between mean values in different groups used single-factor analysis of variance.

\section{Results}

All four groups of starlings transferred from $18 \mathrm{~h}$ light: $6 \mathrm{~h}$ dark to shorter photoperiods showed a significant increase in plasma LH during the course of the experiment ( $11 \mathrm{~h}$ light: $13 \mathrm{~h}$ dark, $F(5,17)=25.23 ; 8 \mathrm{~h}$ light:16 $\mathrm{h}$ dark, $F(5,15)=20.09 ; 5 \mathrm{~h}$ light:19 h dark, $F(6,15)=13.75 ; \quad$ i h light: $23 \mathrm{~h}$ dark, $F(6,15)=30.66, P<0.0001$ in each case). The first significant increase $(P<0.05)$ was recorded after 35 days in the $1 \mathrm{~h}$ light: $23 \mathrm{~h}$ dark and $8 \mathrm{~h}$ light: $16 \mathrm{~h}$ dark groups, and after 38 days in the birds exposed to $5 \mathrm{~h}$ light:19 h dark (Fig. 1). The rate of increase in plasma LH was similar in these three groups; the only time a difference occurred among them was on day 38 , when concentrations were higher under $8 \mathrm{~h}$ light: $16 \mathrm{~h}$ dark than under $5 \mathrm{~h}$ light: $19 \mathrm{~h}$ dark and $1 \mathrm{~h}$ light: $23 \mathrm{~h}$ dark $(P<0.05)$. However, concentrations of LH increased much more slowly in the birds exposed to $11 \mathrm{~h}$ light: $13 \mathrm{~h}$ dark; the first significant increase $(P<0.05)$ occurred on day 63. On all occasions from day 42 to day 63 the concentration of LH in plasma did not differ among animals kept under $1 \mathrm{~h}$ light:23 $\mathrm{h}$ dark, $5 \mathrm{~h}$ light: $19 \mathrm{~h}$ dark and $8 \mathrm{~h}$ light: $16 \mathrm{~h}$ dark, but was significantly lower $(P<0.05)$ in the $11 \mathrm{~h}$ light: $13 \mathrm{~h}$ dark group. After 84 days plasma LH had increased further in the $11 \mathrm{~h}$ light: $13 \mathrm{~h}$ dark group to a value similar to those in the other groups $(F(3,22)=0.81, P>0.05)$.

The castrated starlings maintained under $18 \mathrm{~h}$ light: $6 \mathrm{~h}$ dark photoperiods retained low concentrations of plasma LH, mean values below $0.7 \mu \mathrm{g} \mathrm{l}^{-1}$, throughout the experiment. 


\section{Discussion}

The acquisition of photosensitivity in starlings occurs within 4-6 weeks when photorefractory birds are transferred to a short photoperiod of $8 \mathrm{~h}$ light:16 h dark in the laboratory. During this period there is a gradual increase in hypothalamic LHRH activity, in pituitary content of LH and FSH, and a reduction in pituitary and plasma concentrations of prolactin (Dawson et al., 1986; Goldsmith et al., 1989). Experiments involving measurement of the dynamics of gonadal growth in response to long days, in starlings and in other species, provide evidence of a progressive recovery of photosensitivity with time under short or decreasing photoperiods (e.g. Hamner, 1968; Turek, 1975; Storey, 1978; Boulakoud, 1990; Wilson, 1992).

The experiment reported here used the endocrine phenomenon known as the 'castration response' as an indicator of the acquisition of photosensitivity. This is a spontaneous increase in concentration of LH in plasma that occurs in castrated starlings, and although the amplitude of the increase differs among species (Nicholls et al., 1988; Wilson, 1992), it appears to be a useful correlate of photosensitivity in starlings. (In photosensitive intact starlings, plasma gonadotrophin concentrations are low under $8 \mathrm{~h}$ light: $16 \mathrm{~h}$ dark, and testicular development proceeds slowly. Gonadotrophin secretion is increased if photosensitive intact birds are exposed to long days, and within the range $9.5 \mathrm{~h}$ light: $14.5 \mathrm{~h}$ dark to $16 \mathrm{~h}$ light: $8 \mathrm{~h}$ dark testicular growth rate is proportional to duration of the photophase (Dawson and Goldsmith, 1983; Dawson, 1989).

Starlings that have become photorefractory under long days reacquire a photosensitive condition if exposed to any fixed photoperiod of 12 or fewer hours of light per day, and within the range $12 \mathrm{~h}$ light: $12 \mathrm{~h}$ dark to $8 \mathrm{~h}$ light: $16 \mathrm{~h}$ dark the rate of photosensitive development is inversely proportional to daylength, as indicated by Dawson (1991), Boulakoud (1990), and supported by the responses observed here, where the rate of $\mathrm{LH}$ increase was markedly slower under $11 \mathrm{~h}$ light: $13 \mathrm{~h}$ dark than under $8 \mathrm{~h}$ light: $16 \mathrm{~h}$ dark. An influence of photophase duration upon rate of recovery of photosensitivity has also been reported in canaries, Serinus canarius, in which birds become photosensitive sooner under $8 \mathrm{~h}$ light: $16 \mathrm{~h}$ dark than they do under $11 \mathrm{~h}$ light: $13 \mathrm{~h}$ dark (Nicholls and Storey, 1977). In an experiment in house finches, Carpodacus mexicanus, photorefractory birds were exposed to photoperiods of 6,10 , 12 or $14 \mathrm{~h}$ of light per day and all had become photosensitive when tested after 4 months (Hamner, 1968), but the rate of onset of photosensitivity within this time was not examined.

The results of the experiment reported here provide new information on the range of photoperiodic responses in starlings. The timing and rate of increase in concentrations of $\mathrm{LH}$ in plasma was no faster under $1 \mathrm{~h}$ light:23 h dark and $5 \mathrm{~h}$ light:19 h dark than under $8 \mathrm{~h}$ light: $16 \mathrm{~h}$ dark. Although there were minor differences in $\mathrm{LH}$ at two collections of blood samples, the overall increase was broadly similar under these three photoperiods, especially in comparison with the LH profile under $11 \mathrm{~h}$ light: $13 \mathrm{~h}$ dark. These data suggest a finite limitation to the short-day response of the starlings, at least in terms of the LH increase. (Changes in other endocrine and neuroendocrine parameters characterizing acquisition of photosensitivity have yet to be examined under photoperiods shorter than $8 \mathrm{~h}$ light:16 h dark.) We cannot at this stage distinguish between various possible physiological sites for this limitation. The source might reside with the output of the photoperiodic time-measuring system, alternatively there could be a rate-limiting process within the hypothalamo-pituitary axis.

\section{References}

Boulakoud MS (1990) The role of daily photoperiods and thyroxine in reproduction and photorefractoriness in European starlings (Sturnus vulgaris). PhD Thesis, University of Bristol

Dawson A (1989) Pharmacological doses of thyroxine simulate the effects of increased daylength, and thyroidectomy, decreased daylength on the reproductive system of European starlings Joumal of Experimental Zoology $24962-67$

Dawson A and Goldsmith AR (1983) Plasma prolactin and gonadotrophins during gonadal development and the onset of photorefractoriness in male and female starlings (Sturnus vulgaris) on artificial photoperiods Journal of Endocrinology 97 253-260

Dawson A (1991) Effect of daylength on the rate of recovery of photosensitivity in male starlings (Sturnus vulgaris) Journal of Reproduction and Fertility 93 521-524

Dawson A and Goldsmith AR (1984) Effects of gonadectomy on seasonal changes in plasma $\mathrm{LH}$ and prolactin concentrations in male and female starlings (Stumus vulgaris) Joumal of Endocrinology 100 213-218

Dawson A, Goldsmith AR, Nicholls TJ and Follett BK (1986) Endocrine changes associated with the termination of photorefractoriness by short daylengths and thyroidectomy in starlings (Stumus vulgaris) Joumal of Endocrinology 110 73-79

Follett BK, Scanes CG and Cunningham FJ (1972) A radioimmunoassay for avian luteinizing hormone Journal of Endocrinology 52 359-378

Goldsmith AR and Nicholls TJ (1984a) Prolactin is associated with the development of photorefractoriness in intact, castrated, and testosteroneimplanted starlings General and Comparative Endocrinology 54 247-255

Goldsmith AR and Nicholls TJ (1984b) Recovery of photosensitivity in photorefractory starlings is not prevented by testosterone treatment General and Comparative Endocrinology 56 210-217

Goldsmith AR, Ivings WE, Pearce-Kelly AS, Parry DM, Plowman G, Nicholls TJ and Follett BK (1989) Photoperiodic control of the development of the LHRH neurosecretory system of European starlings (Sturnus vulgaris) during puberty and the onset of photorefractoriness Journal of Endocrinology 122 255-268

Hamner WM (1968) The photorefractory period of the house finch Ecology 49 211-227

Nicholls TJ and Storey CR (1977) The effect of duration of the daily photoperiod on recovery of photosensitivity in photorefractory canaries (Serinus canarius) General and Comparative Endocrinology 31 72-74

Nicholls TJ, Goldsmith AR and Dawson A (1988) Photorefractoriness in birds and comparison with mammals Physiological Reviews 68 133-176

Storey CR (1978) An investigation into the physiological basis of avian reproductive photorefractoriness. PhD Thesis, University of London

Turek FW (1975) The termination of the avian photorefractory period and the subsequent gonadal response General and Comparative Endocrinology 26 $562-564$

Wilson FE (1992) Photorefractory Harris' sparrows (Zonotrichia querula) exposed to a winter-like daylength gradually regain photosensitivity after a lag General and Comparative Endocrinology 87 402-409 